Joanna Ścibek

Uniwersytet w Białymstoku

\title{
Juliusza Słowackiego theatrum mortis - wizja negatywna (na przykładzie Kordiana, Balladyny i Beatryks Cenci)
}

Śmierć z wielką siłą pobudza wyobraźnię poetów romantycznych. Doskonałe potwierdzenie tych słów stanowi twórczość Juliusza Słowackiego, którego stosunek wobec zagadnień „ostatecznych” ewoluuje od traumatycznego przerażenia zaprawionego szczyptą fascynacji ku całkowitemu oswojeniu Tanatosa i jego wyraźnej apoteozie ${ }^{1}$.

Dając wyraz swemu niecodziennemu, ,egzystencjalnemu zainteresowaniu"2 doświadczeniem mortualnym, autor Lilli Wenedy z dużą finezją rozbudowuje w utworach pole semantyczno-leksykalne 'śmierć i zjawiska z nią związane', zamieniając świat przedstawiony swoich dzieł w osobliwe uniwersum tanatyczne, istne theatrum mortis. Podstaw do tego wniosku dostarcza analiza językowa, której zostały poddane trzy dramaty Słowackiego z okresu przedmistycznego, obfitujące w wątki mortualne: Kordian, Balladyna i Beatryks Cenci. Ekscerpcja materiału słownego objęła konteksty realnoznaczeniowe, dotyczące wygasania życia ludzkiego, a otrzymany tą drogą wybór leksyki został rozpatrzony pod kątem obrazu śmierci wyłaniającego się z jej lingwistycznych wykładników.

Przegląd językowych realizacji wskazanej problematyki ujawnia, że ewokowaną przez Słowackiego wizję Tanatosa cechuje swoista ambiwalencja,

${ }^{1}$ Zob. A. Kowalczykowa, Wstęp, w: J. Słowacki, Krag pism mistycznych, oprac. A. Kowalczykowa, Wrocław 1997, s. II-LXXX (tu zwłaszcza: LX-LXV); M. Ursel, ,...larwy w chorobliwej tylko imaginacji wylęte...”. Słów kilka o wyobraźni frenetycznej Juliusza Stowackiego, w: Problemy współczesnej tanatologii. Medycyna - antropologia kultury - humanistyka, t. 11, Wrocław 2007, s. 373-385.

${ }^{2}$ K. Ziemba, Mistycznego Stowackiego marzenie hermeneutyki śmierci, w: Style zachowań romantycznych: propozycje i dyskusje sympozjum Warszawa 6-7 grudnia 1982, red. M. Janion, M. Zielińska, Warszawa 1986, s. 248. 
wyrażająca się we współistnieniu - w ramach jednej, wykreowanej rzeczywistości literackiej - zarówno ułagodzonych przedstawień śmierci, włączających ją w obręb zjawisk bliskich człowiekowi, jak też ich zupełnych przeciwieństw, potęgujących obawę przed siłą kładącą kres ludzkiemu istnieniu. Co jednak znamienne, wyobraźnia poety okazuje się szczególnie uwrażliwiona na ,ciemną" stronę mors, czego dowodem są niezwykle sugestywne negatywne ujęcia śmierci, podkreślające jej wstrząsający, pesymistyczny wymiar.

Zamierzeniem artykułu jest prezentacja najważniejszych lingwistycznych metod zastosowanych przez Słowackiego w celu uwydatnienia przykrych aspektów doświadczenia mortualnego w trzech wymienionych wyżej dziełach $^{3}$. Służyć temu będzie omówienie językowych nominacji desygnatów z kręgu semantycznego 'śmierć' oraz ich istotnych konotacji, a także opis tropów stylistycznych budujących drastyczny wizerunek mors. Dodatkowo refleksja obejmie inne - wykraczające poza tekstową ekwiwalencję znaczeniową wyrazów - strategie poetyckie, umożliwiające polskiemu wieszczowi zaakcentowanie grozy śmierci i wyeksponowanie jej posępnej natury.

Głównym źródłem negatywnych uczuć zogniskowanych wokół kwestii „finalnych” są tanatyczne verba propria, bezpośrednio nazywające zjawiska związane z ludzką skończonością ${ }^{4}$ Ze względu na swój konwencjonalny charakter nie oddają one jednak specyfiki wizji śmierci zarysowanej w interesujących mnie utworach $^{5}$ i dlatego zostają wyłączone z niniejszych rozważań.

\section{Figury stylistyczne $\mathrm{z}$ „tanatycznym” elementem leksykalnym oraz zastępniki nazewnicze ${ }^{6}$}

Podstawę rekonstrukcji - szeroko rozumianej - negatywnej kreacji mors ukazanej w Kordianie, Balladynie i Beatryks Cenci stanowią niezleksykalizowane przekształcenia semantyczne z komponentem wyrazowym należącym do pola znaczeniowego 'śmierć', mającym najczęściej postać rzeczowniko-

3 Zagadnienia związane z przedstawianą problematyką omawiam jedynie w wyborze, przy znacznym ograniczeniu leksykalnego materiału ilustracyjnego.

4 Zob. A. Krzyżanowska, Eufemiczne wyrażanie śmierci w języku polskim i francuskim, w: Problemy frazeologii europejskiej, t. 1, red. A.M. Lewicki, Warszawa 1996, s. 93.

5 Mam tu na myśli verba propria z kręgu semantycznego 'śmierć' występujące w kontekstach niemetaforycznych, w swoich standardowych znaczeniach.

${ }^{6}$ Analizując negatywną wizję doświadczenia mortualnego ukazaną w Kordianie, Balladynie i Beatryks Cenci, przyjmuję koncepcję opisu ideowego, w którym na pierwszy plan wysuwają się sensy niesione przez językowe wykładniki śmierci, dlatego też figury stylistyczne z ,tanatycznym” komponentem leksykalnym oraz zastępniki nazewnicze omawiam łącznie jako konceptualną całość. 
wego verbum proprium, a także określenia o charakterze substytucyjnym ${ }^{7}$, nazywające realia tanatyczne. To właśnie te środki językowe odpowiadają za unikatowość optyki mortualnej Słowackiego, zaprezentowanej w analizowanych dramatach.

Wśród tropów stylistycznych konstytuujących przygnębiający portret Tanatosa przeważają personifikacje oraz metafory, odznaczające się zróżnicowanym stopniem oryginalności. Mamy tu bowiem do czynienia zarówno z tropami odwołującymi się do tradycyjnych konceptualizacji mors, jak i takimi, które na zasadzie łańcucha skojarzeń zostają rozwinięte w większe kompleksy wyobrażeniowe, ujawniające atrybutywne cechy imaginarium poety.

Szczególnie zajmujące wydają się przykłady wykorzystania przez Słowackiego - w roli tworzywa poetyckich uosobień śmierci oraz innych poświęconych jej figur językowych - utartych połączeń wyrazowych. Zdaniem Anny Pajdzińskiej tego typu działaniom sprzyja natura związków frazeologicznych, będących konstrukcjami nieregularnymi pod względem znaczeniowym ${ }^{8}$, często o metaforycznej genezie, z łatwością wchodzącymi w interakcje z pozostałymi składnikami tekstu, a przez to niezwykle podatnymi na wszelkie operacje sensotwórcze ${ }^{9}$. Słowacki umiejętnie odświeża frazeologizmy, czyniąc je obiektem zabiegów modyfikujących, prowadzących do zatarcia treści idiomatycznej, przy jednoczesnej rewitalizacji znaczeń literalnych, stanowiących podwalinę niestandardowych, artystycznych interpretacji fenomenu wygasania życia.

Już sama świadomość efemeryczności ludzkiego istnienia okazuje się dla postaci dramatycznych niezwykle dotkliwa. Świadczy o tym rozbudowana personifikacja, zastosowana przez Słowackiego w Kordianie, zawierająca w swej strukturze metaforę anioł śmierci, odwołującą się do jednego z ulubionych motywów obrazowania poety ${ }^{10}$ : „Ta cicha jesień, co drzew trzęsie

${ }^{7}$ Zastępniki nazewnicze, których rzecz dotyczy, eufemizują śmierć w planie signifiant (wyrażania), gdyż pozwalają uniknąć, obwarowanego szeregiem negatywnych reakcji i skojarzeń, mówienia o śmierci expressis verbis. Silniej zdają się jednak oddziaływać na czytelnika wyobrażenia i oceny przekazywane przez ten zespół środków językowych, sytuujące doświadczenie mortualne wśród jakości budzących lęk, smutek, awersję itd. $Z$ tego też powodu środki te analizuję w ramach charakterystyki negatywnej odsłony Tanatosa.

${ }^{8}$ Znaczenie całości konstrukcji nie odpowiada sumie znaczeń poszczególnych komponentów.

9 Zob. A. Pajdzińska, Frazeologizm jako podstawa obrazu poetyckiego, „Język Polski” 1991, z. 7/8, s. 268.

${ }^{10}$ Andrzej Boleski wśród głównych motywów obrazowania Słowackiego wymienia anioła. Jedną z realizacji tego motywu jest aniol śmierci, występujący nie tylko w Kordianie, ale też w Wacławie oraz - jako anioł zgonu - w Beniowskim. Natomiast w postaci wykończonego wyobrażenia pojawia się on w Anhellim (Eloe). Zob. A. Boleski, Stownictwo Juliusza Stowackiego, Wrocław 1957, hasło Aniot, s. 13-14. 
szczytem,/ Co na drzewach liście trujel I różom rozwiewa czoła,/ Podobna do śmierci anioła,/ Ciche wyrzekła słowa do drzew: "Gińcie drzewa!»/ Zwiędły - opadły"11. Wskazana przenośnia ma kształt ustabilizowany (prawdziwie oryginalne metafory Słowackiego, wyróżniające się niestandardową łączliwością semantyczno-gramatyczną, powstawały przede wszystkim w erze genezyjskiej ${ }^{12}$ ), jednak dzięki swym właściwościom uplastyczniającym doskonale dopełnia wizję jesiennej agonii natury obserwowanej przez Kordiana, intensyfikując melancholijną wymowę obrazu. Co prawda, przedmiotem niniejszej analizy są tylko te konteksty, w których to człowiek podlega śmierci, niemniej warto zauważyć, iż z losu obumierającej przyrody wrażliwy młodzieniec odczytuje także smutną zasadę własnej egzystencji.

Fakt ten potwierdza kolejna złożona figura metaforyczna: „Myśl śmierci z przyrodzenia $w$ dusze sie przelewa;/ Posępny, tęskny, pobladły,/ Patrzę na kwiatów skonanie/ I zdaje mi się, że mię wiatr rozwiewa" (Kor, 104). Przenośnie kategorialne - użycie w stosunku do kwiatów leksemu skonanie przyporządkowanego śmierci ludzkiej oraz posłużenie się czasownikiem rozwiewać $\mathrm{w}$ odniesieniu do człowieka, a nie do przedmiotów czy elementów roślinnych - umacniają sensy wpisane w metaforę główną i uprawomocniają utożsamienie myśli śmierci z poczuciem tragicznej jedności wszelkiego bytu w procesie przemijania, stopniowego zamierania, rozpadu form ${ }^{13}$.

Przygnębienie, a zarazem lęk, wywołuje niepewność co do istoty śmierci. Pełen wahań i wątpliwości Kordian, rozważając możliwość odebrania sobie życia, mówi: „Śmierć patrzy w oczy moje dwustronnym obliczem, / Jak niebo nad głowami i odbite $w$ wodzie.../ Prawda lub omamienie - lecz wybierać trudno,/ Gdzie nie można zrozumieć..." (Kor, 119). Wolno przypuszczać, że motywacją powyższego tropu stała się spetryfikowana metafora śmierć patrzy komuś w oczy 'śmierć komuś zagraża'14. Rozszerzenie frazeologizmu o dodatkowy

${ }_{11}$ J. Słowacki, Kordian, w: Dzieła wybrane, t. 3, Wrocław 1989, s. 104. Dalej stosuję skrót Kor, liczba w nawiasie oznacza numer strony, na której znajduje się przytoczony cytat.

12 T. Skubalanka, Juliusz Stowacki - artysta stowa, ,Język Polski” 1999, z. 5, s. 348.

${ }^{13}$ Analizowane motywy mają kilka poziomów symbolicznej egzegezy. Obraz jesiennej agonii natury nie sprowadza się jedynie do wykładni wanitatywnej, ale stanowi też metaforę przeżywanego przez Kordiana kryzysu egzystencjalnego, wywołanego bolesnym przekonaniem o nieautentyczności i bezcelowości własnego istnienia, ogołoconego z wszelkich wartości, a zatem jawiącego się jako śmierć za życia. Więcej na ten temat: M. Piwińska, Zle wychowanie, Gdańsk 2005, s. 65-133; M. Janion, M. Żmigrodzka, Romantyczne tematy egzystencji, w: Nasze pojedynki o romantyzm, red. D. Siwicka, M. Bieńczyk, Warszawa 1995, s. 9-25.

${ }^{14}$ Ze względu na przejrzystość wywodu, a także nieuniknioną niejednorodność oznaczeń, wynikającą z użycia słownika w wersji elektronicznej, rezygnuję z podawania dokładnej lokalizacji poszczególnych eksplikacji znaczeniowych. Podczas analizy wykorzystano następujące pozycje: Nowy słownik języka polskiego, red. E. Sobol, Warszawa 2002; Słownik języka 
komponent - dwustronnym obliczem - na którym spoczywa ciężar antropomorfizacji, nie tylko nadaje zacytowanej frazie znamię poetyckości (poetyzm oblicze), ale też pozwala - dzięki zaktualizowaniu sensów dosłownych - na upostaciowienie śmierci i zwrócenie uwagi na bliskość spotkania z nią oraz jej tajemniczą naturę. $Z$ kolei osadzenie personifikacji wewnątrz rozbudowanego porównania umożliwia czytelnikowi wyjaśnienie zagadki janusowego oblicza Tanatosa: niebo nad glowami oraz odbite w wodzie wskazuje na dramatyczny stan zawieszenia pomiędzy prawdą a złudzeniem w kwestii, czy zgon to brama do dalszego życia czy też ostatecznego unicestwienia.

Myśl ta staje się bardziej klarowna, jeśli w rozważaniach uwzględni się dwa synonimy kontekstowe śmierci $i^{15}$, występujące w sąsiedztwie omówionego wcześniej obrazu, a mianowicie - serię wyrazową ból, chwila jedna, ciemno, jasność: „Nabity - niechaj krzemień na żelazo pada.../ Ból, chwila jedna, ciemno - potem jasność błyśnie” (Kor, 119); oraz zaimek nic: „Lecz jeśli nie zaświeci nic? [...] Ha! więc będę zwyciężony niczem?" (Kor, 119). Zestawione w jednym rzędzie określenia ekwiwalentne wobec leksemu śmierć odzwierciedlają stereotypową sekwencję wyobrażeniową dotyczącą idei śmierci jako potencjalnej transgresji, podczas gdy odmienność konotowanych przez nie sensów nadaje projektowanemu samobójstwu bohatera rangę aktu epistemologicznego i stanowi wyraz postrzegania momentu mortualnego w kategoriach progu, za którym istnieje inna forma egzystencji (ból, chwila jedna, ciemno, jasność) lub rozpościera się przerażająca nicość (nic).

Na ową dwu-licowość (!) śmierci akcent pada także w Balladynie, z tym że refleksja tanatyczna zostaje tu przeniesiona z płaszczyzny filozoficznej w sferę ludzkich emocji. W ekspresywnej skardze Filona, utrzymanej w tonie sentymentalnym, mors przywdziewa kostium „fałszywca” i okrutnika, ograbiającego zmarłą Alinę ze wszystkiego, co najcenniejsze: „Jak ona wczoraj musiała być czuła!/ Jak do niej wianek przypadał weselny!/ Jak mogła kochać!... A dziś!... śmierć obłudnal Życie wydarła" ${ }^{\prime \prime}$. Obdarzenie śmierci epitetem charakteryzującym obłudna 'człowiek fałszywy, dwulicowy', przysługującym istocie ludzkiej, generuje psychizację tego abstrakcyjnego fenomenu, a co za tym idzie - jego artystyczną konkretyzację w postaci osoby. Również w tym przypadku metaforyczna transfiguracja zdaje się mieć swoje źródło w delek-

polskiego PWN (wersja elektroniczna), dostęp online: http://sjp.pwn.pl/; S.B. Linde, Stownik języka polskiego, t. 1-6, wyd. 2, Lwów 1854-1860; S. Skorupka, Słownik frazeologiczny języka polskiego, t. 1-2, wyd. 4, Warszawa 1984.

${ }^{15}$ Desygnatem wskazanego leksemu jest śmierć rozpatrywana w połączeniu z ewentualnymi okolicznościami post mortem.

16 J. Słowacki, Balladyna, w: Dzieła wybrane, t. 3, Wrocław 1989, s. 384. Dalej stosuję skrót Bal, liczba w nawiasie oznacza numer strony, na której znajduje się przytoczony cytat. 
sykalizacji stałego związku wyrazowego (lub też luźno do niego nawiązywać), tym razem: śmierć wydarła kogo 'ktoś umarł'. Przekształcenie schematu relacji syntaktycznych, polegające na zamianie dopełnienia bliższego na domyślne dalsze [kto - kogo > kto - (komu) - co], kieruje treść wypowiedzi na wyrządzoną bohaterce krzywdę, natomiast użycie intensivum wydarła, kategorii typowej dla twórczości Słowackiego ${ }^{17}$, uwydatnia zachłanność i drapieżność śmierci. Wspomnianą obłudę Tanatosa podkreśla dodatkowo wydobyty przez dramaturga kontrast pomiędzy zachowanymi możliwościami wczoraj a straconymi szansami $d z i s ́$ oraz częste w poezji (np. Tren VII Jana Kochanowskiego) sprzężenie słownictwa z mortualnego kręgu znaczeniowego z leksyką obrzędów weselnych.

Przedstawienie mors na wzór czyhającego wroga realizuje jeszcze jedna figura stylistyczna wprowadzona przez Słowackiego do tekstu Balladyny: „Bóg ciebie przekonał, / Na samym wstępie u złotego tronu, Że przy tych szczeblach stoi widmo zgonu/ I czeka na nas" (Bal, 485). Pojawia się tu wariant utartego połączenia wyrazowego widmo śmierci z synonimicznym wobec rzeczownika śmierć określeniem zgon. W obrębie zestawienia niesiona przez leksem widmo cecha zagrożenia zostaje przetransponowana na śmierć, w wyniku czego Tanatos jawi się jako straszna i niebezpieczna siła. To jednak nie wszystko. Ekspresja omawianej wizji rodzi się także w następstwie zastosowanego przez poetę chwytu personifikacji, na który może wskazywać zmodyfikowana forma konstrukcji widmo zgonu czeka na kogo, mającej swój pierwowzór - najprawdopodobniej - we frazie widmo śmierci (zgonu) czeka kogo. Co ciekawe, dokonując uosobienia śmierci, Słowacki wyzyskuje potencjał kreacyjny zawarty w polisemii leksemu widmo, oznaczającego przecież nie tylko 'perspektywę czegoś złego, grożącego komuś', ale i 'nierealną postać lub fantastyczne zjawisko będące złudzeniem wzrokowym lub wytworem imaginacji’.

Antropomorficzne kształty otrzymuje śmierć również za sprawą referencji do jej średniowiecznych wyobrażeń ${ }^{18}$. W Beatryks Cenci szalejący z rozpaczy Giani, pragnąc podzielić los swej ukochanej, skazanej na ścięcie, przyznaje się do bratobójstwa i woła: ,śmierć kryjaca się pod waszym stołem/ Wywołam żótta, cicha-ale wściekła.../ O! śmierci-wystap... i badź urodzonal Słowami sqdu!... Śmierci - ja cię pragnę... / A ty mię zimnq twojq zetnij kosq"19. O wizualizacji mors w postaci kostuchy informuje jej nieodłączny atrybut, czyli kosa. Jednak - jak konstatuje Stefania Skwarczyńska - tradycyjne stylizacje

${ }_{17}$ T. Skubalanka, op.cit., s. 347.

${ }^{18}$ Do średniowiecznego wyobrażenia śmierci Słowacki wróci także w okresie mistycznym, m.in. w Księdzu Marku i Śnie srebrnym Salomei.

19 J. Słowacki, Beatryks Cenci, w: Dzieła wybrane, t. 4, Wrocław 1989, s. 89. Dalej stosuję skrót BC, liczba w nawiasie oznacza numer strony, na której znajduje się przytoczony cytat. 
stanowią zwykle dla Słowackiego przyczynek do tworzenia własnych, niepowtarzalnych $^{20}$. Tak jest i tym razem. Obok emanującej z wizji średniowiecznej odrazy wobec kościotrupa, sugerowanej epitetem żółta, zyskującym dzięki bliskości określeń cicha i wściekła walor emocjonalny ${ }^{21}$, poeta włącza do sporządzanego przez siebie portretu śmierci nowy odcień znaczeniowy: śmierć, zmuszona do ukrywania się, choć nadal groźna i agresywna, zostaje swoiście upodlona.

Warto w tym miejscu wspomnieć o pewnej metaforze „rolniczej”22, zaproponowanej przez Słowackiego w Beatryks Cenci, współpracującej - choć w sposób niejawny - z opisaną wyżej konceptualizacją śmierci: „Zebrałyśmy zbrodni plon,/ Reszta jest dzietem dla katów i wron" (BC, 77). Słowa te, wypowiedziane przez Erynie, boginie zemsty, a zgodnie z zamysłem Słowackiego - piekielne sługi tragicznego losu, stanowią przykład iście mistrzowskiej kumulacji znaczeń mortualnych. Nie dość bowiem, że ujawniają fatalistyczną logikę zaszłych (morderstwa) i antycypowanych (środek represyjny w wymiarze sprawiedliwości) zgonów, będących udziałem postaci dramatycznych, to jeszcze odsyłają do trzech ważnych motywów tanatycznych, funkcjonujących w kulturze śródziemnomorskiej. Przez aluzję do frazy: Śmierć zbiera (krwawe) żniwo 'śmierć pochłania ofiary' odżywa w nich - właściwe wiekom średnim, ale zadomowione w sztuce wielu epok - wyobrażenie mors-bezlitosnego żniwiarza. Z kolei słowo zbrodnia, wyposażone w sem ujemnej waluacji, podkreśla ten wymiar zjawiska, który wiąże się z potępieniem i karą, czego potwierdzeniem jest fakt przywołania przez poetę figury kata oraz wrony. $\mathrm{O}$ ile ta pierwsza nie wymaga komentarza, o tyle w przypadku drugiej należy nadmienić, iż na leksem wrona zostają przeniesione semantyczne wartości naddane wynikające $\mathrm{z}$ symboliki innego spokrewnionego z tym ptakiem padlinożercy, a mianowicie - kruka ${ }^{23}$, wskutek czego wrona staje się w Beatryks Cenci znakiem śmierci haniebnej, poniesionej na szubienicy czy szafocie.

Pozostając w kręgu zagadnień traktujących o najwyższym wymiarze kary, nie można pominąć w niniejszym przeglądzie tropu, w którym szubienica zostaje wzmiankowana eksplicytnie, a który stanowi kanwę dla większego ze-

20 S. Skwarczyńska, Ewolucja obrazów u Słowackiego, Lwów 1925, s. 122-123.

21 Ibidem, s. 116.

${ }^{22}$ Określenie ukute przez Irinę Sandomirską w stosunku do takich ustalonych metafor, jak: wiosna życia, siać śmierć, śmierć zbiera krwawe żniwo itp. Analogie formalne i treściowe pozwalają na użycie tego terminu również w odniesieniu do metafory zastosowanej przez Słowackiego w Beatryks Cenci. Zob. I. Sandomirska, O metaforach życia i śmierci w stałych zwiazkach wyrazowych w języku rosyjskim, w: Językowy obraz świata i kultura, red. A. Dąbrowska, J. Anusiewicz, Wrocław 2000, Język a Kultura, t. 13, s. 363.

${ }^{23}$ Zob. W. Kopaliński, Słownik symboli, Warszawa 1991, hasło Kruk, s. 172. 
społu imaginacyjnego, obecnego we wszystkich trzech dramatach, w osobliwy sposób unaoczniającego koszmar śmierci. Fragmenty tekstu wyekscerpowane z poszczególnych dzieł ilustrują kolejne fazy rozwoju tego, upiornego w swej wymowie, wyobrażenia.

W ostatnich chwilach przed egzekucją Kordian, przeklinając plugawość rodzaju ludzkiego, mówi: „Niech szubienic drzewa/ W ogrodach miejskich rosna jak szpalery, / Niech się w ogrody takie tłum wylewa/ Śmiechom przyjazny, a łzom nienawistny;/ Niech niańki w ogród szubienic bezlistny/ Prowadzą dziatki, by tam dla zabawy/ Grzebały piasek krwią męczeńską rdzawy" (Kor, 185). Kształt drewnianej konstrukcji „obwieszonej” skazańcami oraz materiał, z jakiego jest ona wykonana, uzasadniają dostrzeżenie - wprawdzie dość tradycyjnej, lecz mimo to wywołującej silne wrażenie - analogii pomiędzy szubienicą a drzewem, prowadzącej do powstania metafory (bezlistne) szubienic drzewa.

Kolejnym ogniwem w opisywanym ciagu skojarzeniowym nie jest już proste zestawienie obu obiektów. Na tym poziomie dochodzi bowiem do ich utożsamienia, a w konsekwencji - także głowy skazańca z owocem. Panfilio z Beatryks Cenci, kupując pomarańcze na placu Porta Popolo, namawia przekupkę, by dołożyła mu za darmo jeszcze jedną sztukę. Kobieta zaś odpowiada: „Piąta na drzewie wisi - idź pod drzewo/ I urwij sobie... piata z szubienicy...” (BC, 101).

Tożsamość ta zostaje ugruntowana za pomocą aluzji - oto na spornej gruszy kończą swój żywot nieszczęśni rebelianci z Balladyny: „Pierwsi buntownicy/ Już zgromadzeni pod maćkowa gruszę;/ A ta się cieszy, że do siego roku/ Dwa razy będzie nosiła owoce" (Bal, 478).

Ostatni etap ewolucji wyobrażenia stanowi redukcja komponentu wyjściowego drzewa/szubienicy/szafotu i usamodzielnienie się obrazu głów-owoców, który występuje m.in. w Beatryks Cenci: „Ha! ojcobojce! dobrze wam tak, dobrze!/ Chcecie pomarańcz... hej! - hej! - parricidi,/ Chcecie pomarańcz, co pod zębem cieknal Czerwonq ślinq?... ho! ho! - apelcyny!/ Czerwone wszystkie głowa w głowe..." (BC, 101). Czerwony sok pomarańczy, przez skojarzenie z krwią, zapowiada makabryczną śmierć Cencich z ręki kata i wskazuje na kolejną realizację, wręcz obsesyjnie powracającego w twórczości poety, fantazmatu ściętej głowy.

Dokonując niekorzystnej charakterystyki Tanatosa, Słowacki odwołuje się do zróżnicowanych typologicznie kategorii opisu: intelektualnych, emocjonalnych, a przede wszystkim - sensorycznych, wśród których dominują impresje wzrokowe. W Beatryks Cenci można jednak spotkać także przykład interpretacji mors przez pryzmat doznań powonieniowych. Eumenidy, podżegające bohaterów do strasznych zbrodni, mówią bowiem: „Śmierć nie cuchnie od nas 
w dzień...” (BC, 26). Leksem cuchnać konotuje uczucie odrazy, co sprzyja przedstawieniu śmierci jako „materii” wywołującej wstręt, przy czym - zgodnie z odczytaniem metaforycznym - chodzi tu o jej „smród” moralny, gdyż przytoczony cytat odnosi się do śmierci nienaturalnej, równoznacznej z krwawymi morderstwami.

Działania kończące się odebraniem życia drugiemu człowiekowi podlegają u Słowackiego negatywnej aksjologizacji ${ }^{2}$. Jej „narzędziem” stają się w rozpatrywanych utworach m.in. peryfrazy leksemu zabójstwo, zbudowane z hiperonimów opatrzonych wartościującymi epitetami, zyskującymi w tekście walor moralny lub emocjonalny. Godne uwagi jest to, że w zakresie dookreślania owych hiperonimów poeta chętnie korzysta ze stałego repertuaru wykładników, charakteryzujących jakości budzące awersję, wstyd oraz trwogę, tworząc przy ich użyciu różnorodne kombinacje:

- okropny 'budzący grozę, straszny, rozpaczliwy, beznadziejny': „Omal tobie, Boże,/ Nie podziękuje, że mi ona kradnie/ Czyn ten okropny” (Bal, 465); „Ja, nieszczęsna matka,/ Na rzecz okropnq ważę się... straszniejsza/ Rzeczą przed wami usprawiedliwiona” (BC, 10); „Okropna zbrodnia - ludzie/ zamieniają się w Etiopów" (BC, 58);

- ohydny 'bardzo brzydki; budzący wstręt, odrazę w sensie moralnym, obrzydliwy, odrażający’: „Widzicie wszyscy, jaka ohydna zbrodnia...” (BC, 23);

- haniebny 'przynoszący ujmę, wstyd, niecny, nikczemny': „Widzicie wszyscy, jaki czyn haniebny!” (BC, 23);

- straszny 'wzbudzający strach, grozę, przerażenie, przejmujący lękiem': „Mary, pomożcie mi w robocie strasznej!” (BC, 10); „Ale jeśli uwierzył - jeśli przechodniowi/ Zbłąkanemu opowie straszna zbrodnię pani” (BC, 433);

- piekielny 'przynoszący zło, budzący strach i grozę': „Ja tam nie pójdę nie, to rzecz piekielna!' $(\mathrm{BC}, 16)$;

- ciemny (na płaszczyźnie symbolicznej) 'zły, niemoralny, ohydny': „Ciemna zbrodnia - straszna zbrodnia” (BC, 57).

Zwłaszcza ostatni przymiotnik, w sposób niezwykle sugestywny uwypukla nieetyczny aspekt śmierci-mordu, ujawniając jej niebezpieczne koneksje ze sferą zła. Potwierdzają to dwa okazjonalne zastępniki nazewnicze, ekwiwalentne wobec leksemów zabić / zabijać: „Trzeba korzystać, córko, i dzisiejszal Noc ofiarować bogom tajemniczym/ Ciemnej przyszłości... Kazałam zawołać/ Księdza...” (BC, 15); „Tak, kto bez Boga... lecz z ciemnymi duchy/ Chce porządkować świat... często go łamie/ Bóg tak jak ciebie" (BC, 107). Również

${ }^{24}$ Fakt ten wynika z samej natury owych działań. Nieco inaczej sprawa wygląda w przypadku patriotycznej motywacji zabójstwa (głównie w Kordianie), gdzie ocena ma raczej charakter ambiwalentny, z tendencją do usprawiedliwienia niemoralnego czynu. W związku z tym prezentowane zastępniki nazewnicze pochodzą przede wszystkim z Balladyny i Beatryks Cenci. 
tytułowa bohaterka dramatu, ze względu na popełnione ojcobójstwo, zostaje nazwana przez marę swego ojca ciemna Hekate: „Ciemna Hekate, wstań... i chodź w podziemie...” (BC, 51).

Doniosłą rolę w ukazywaniu horroru śmierci, związanego z jej fizyczną strona, odgrywają $\mathrm{w}$ analizowanych dramatach te figury stylistyczne, które obrazują rozmaite okropieństwa dotykające ludzkie ciało w momencie pozbawiania kogoś (lub siebie) życia. Na pierwszy plan wysuwają się tu metonimiczne konstrukcje omowne wskazujące na sens zadawania śmierci przez odwołanie się do bezpośrednich przyczyn zgonu zachodzących w sferze somatycznej człowieka, np.: „Wstań! mów! bo szpada gardlo ci otworzę” (Kor, 167); „Wyznaj... gdzie ona?... Wyznaj, bo na Boga,/ Sztylet uczujesz w sercu” (BC, 52); „Pomogę mieczem... Ona w sercu? wydrę serce!/ Ona w mózgu? więc mózgiem na ściany rozprysnę!" (Kor, 195). Czasem w tym samym celu poeta tworzy interesujące przenośnie, jak chociażby: „Nóż ten zatruty piersi mi rozerwie,/ Jeżeli w ręce męża wpadnę żywa, I serce moje bijace ukasi/ Jak żądto osy" (Bal, 475). Dzięki poetyckiej animizacji „śmiercionośne” narzędzie przemienia się w drapieżną bestię.

Niszczycielska moc Tanatosa funduje człowiekowi uwłaczający finał w postaci truchła. Tę smutną prawdę przekazuje jedna z oryginalniejszych metafor występujących w Kordianie, sprzężona z comparatio, odsłaniająca tragedię ludzkiego ciała skazanego na pośmiertną transformację: „Cara zamknatem jak miecz kata goty/ W pochwe zgnilizny [...] niechaj go rdza toczy!" (Kor, 195). Analogia pomiędzy carem a mieczem znajduje kontynuację w parze: zgnilizna - rdza i „domaga się” uzupełnienia kolejnego zestawienia, opartego na wspólnej cesze 'bycia zewnętrzną powłoką', członem paralelnym wobec pochwy. W ten sposób rodzi się wyobrażenie rozkładających się zwłok, odzierające śmierć $\mathrm{z}$ wymiaru sakralnego i degradujące ją do poziomu ohydy.

Pesymistyczna wizja doświadczenia mortualnego wyłania się także z nielicznych określeń zastępczych oraz tropów stylistycznych skoncentrowanych wokół tematu okoliczności pozgonnych. Za punkt wyjścia do dalszych rozważań posłuży eufemistyczna peryfraza umarlego / zabitego utworzona przez Słowackiego w Kordianie. Przynaglani do zdeklarowania się za carobójstwem lub przeciwko niemu dwaj spiskowcy kopiący grób dla zabitego szpiega wołają do pozostałych konspiratorów: „Wiemy! Wiemy!/ My dla głuchego człeka mogiłę kopiemy,/ Lecz sami z łaski Boga nie głuszce" (Kor, 156). Omownia ta ma w dużej mierze charakter doraźny, niemniej przypomina o pewnej ważnej, lecz przykrej oczywistości - zmarły to człowiek pozbawiony możliwości wszelkiej percepcji. Ta nieczułość odejmuje mu rysy osoby, którą dawniej był, i upodabnia go do martwej rzeczy. 
Tragicznym przeznaczeniem zwłok jest trumna, czyli metonimiczne jęczące drzewo (BC, 54), a ich śmiertelnym odzieniem i jedyną ozdobą - gałązka smutnego cyprysu: „Weź tę gałązkę smutnego cyprysu,/ Abyś miał ubrać w co - ostygłe ciało/ Twego martwego przyjaciela" (BC, 32). Epitet smutny, wyposażony w ładunek ekspresywny, potęguje uczucie żalu wpisane w symbolikę cmentarnej rośliny.

Oprócz tego posępny pejzaż śmierci tworzą: peryfraza stanowiąca określenie grobu w Balladynie oraz funeralna metafora $\mathrm{z}$ Kordiana. Zastanawiając się nad tym, czy w mogile ludzie marzą o szczęściu, Filon mówi do Pustelnika: „Ciało jej [Aliny - J.Ś.] leży pod zimnym kamieniem” (Bal, 419). Sensy niesione przez wykładnik tej konstrukcji omownej sprawiają, iż miejsce ostatniego spoczynku zmarłego kojarzy się z czymś odpychającym, wzbudzającym silną niechęć. Co prawda człowiek może w końcu odnaleźć w nim spokój, ale jest to spokój wieczny, a przez to zatrważający, gorzko wynagradzający ofiarę składaną z własnego życia. Dlatego Kordian, poświęcając się dla dobra ojczyzny, porównuje siebie do owego biblijnego najemnika, ,któremu Chrystus nie odmówił płacy,/ [...] A tą zapłata jest grób cichy, ciemny" (Kor, 185).

Podobny pesymizm bije z zastępników nazewniczych krypty, które poeta wkłada w usta Prezesa z Kordiana: „Ciemna jaskinio trumien, znam ja ciebie!” (Kor, 143); „To szpieg... Więc go zakopać tam - w kącie ciemnicy” (Kor, 155). Joanna Rychter zauważa, że „podziemne obszary [...] mają u Słowackiego, jak $\mathrm{w}$ całym romantyzmie, ujemne konotacje, wyrażone epitetem czarny"25. Za przyczyną pokrewieństwa semantycznego konotacje te udzielają się również przymiotnikowi ciemna oraz rzeczownikowi ciemnica, przez co obraz losów post mortem rysuje się w niezwykle ponurych barwach. Jednocześnie trzeba dodać, że mamy tu do czynienia z negatywnością podwójną - ciemna tonacja odsyła do śmierci, ale wskazuje też na moralną dwuznaczność konspiracyjnych działań.

Czarny to kolor żałoby. W Beatryks Cenci przywdziewają ją - zgodnie z ustaloną symboliką - poetycko ustylizowane cyprysy: „Cóż? - żadnej odpowiedzi... i tylko cyprysy,/ Stugi grobów, ruszyły się czarne przy ścianach/ Jakby chciały się tu zejść - otoczyć mnie wkoło/ I zacząć ze mną o mej miłości rozmowę" (BC, 72). Ornamentacyjna peryfraza (czarne) stugi grobów pełni zarazem funkcję personifikująca. Dzięki temu zabiegowi cmentarne drzewa zostają obdarzone wrażliwością i zdolnością współodczuwania, stając się jedynymi towarzyszami bohatera $\mathrm{w}$ jego trudnej samotności.

Na koniec warto zaznaczyć, iż mogiła nie obrasta u Słowackiego jedynie w negatywne odczytania. Świadczą o tym m.in. dwie metafory z Kordiana:

25 J. Rychter, Funkcjonalno-semantyczna sprawność peryfraz w „Beniowskim” Juliusza Stowackiego, „Poznańskie Spotkania Językoznawcze” 2002, t. 8, s. 30. 
„Oni tu miecze jasne wyostrzq na grobie” (Kor, 145); „Ja bym was poruszył śpiewem;/ [...] A wstalibyście wszyscy jako grobyotwarte,/ Rzucajace mścicieli" (Kor, 153). Leksemowi grób - stanowiącemu jedno z głównych słów kluczy literatury romantycznej ${ }^{26}$ - przydaje poeta symboliczne znaczenie schronienia „dla tego, co może mieć przypisany znak nieśmiertelności” ${ }^{27}$. Mogiła zostaje więc nobilitowana do rangi rezerwuaru sił życiowych narodu i to w jej „łonie” mają się począc mściciele jego krzywd.

\section{Tanatyczna semantyka $k r w i$ oraz nazw czerwieni ${ }^{28}$}

Przerażająca kreacja Tanatosa, której istotny rys stanowi okropieństwo śmierci, to w Kordianie, Balladynie i Beatryks Cenci także rezultat konsekwentnie realizowanego, a znamionującego wyobraźnię frenetyczną Słowackiego, obrazowania opartego na motywie krwi oraz - pozostającej z nią w ścisłym związku - czerwonej barwie.

Nie bez powodu badacze literackiego dorobku polskiego wieszcza zwracają uwagę na jego doskonale rozwinięty zmysł plastyczny. Często bowiem „Słowacki-kolorysta wspomaga Słowackiego-dramaturga” ${ }^{29}$ czy Słowackiego-poetę. Tak się właśnie dzieje w przypadku omawianych utworów, w których śmierć - nieważne, czy ukazana na scenie, czy jedynie zasygnalizowana - chętnie przyobleka się w całą gamę czerwieni, sygnując swe dominium (w obrębie wykreowanego uniwersum) strumieniami krwi, zarówno faktycznie przelewanej, jak i pojawiającej się na prawach metafory; przywoływanej eksplicytnie, ale i ewokowanej dzięki asocjacjom kolorystycznym ${ }^{30}$.

Krwią „odmalowywaną” przez poetę na płaszczyźnie wyobrażeniowej wskazanych utworów „przesiąka” ich tkanka językowa. Zostaje ona nasycona różnymi formami leksemu nazywającego ów desygnat, jego derywatami oraz wyrazami należącymi do pola znaczeniowego barwy czerwonej. Należy jednak poczynić w tym miejscu dwa istotne zastrzeżenia. Po pierwsze, stopień

${ }^{26}$ Zob. E. Stachurski, Słowa-klucze polskiej epiki romantycznej, Kraków 1998, s. 138-141.

27 U.M. Łebkowska, Język czterech żywiołów: kreacje obrazów w liryce Juliusza Słowackiego, Kraków 2006, s. 24.

28 Wnioski zawarte w tej części pracy wiele zawdzięczają ustaleniom Marii Cieśli zaprezentowanym w artykule: „Beatryks Cenci” - czerwona tragedia, „Ruch Literacki” 1978, R. XIX, z. 1, s. 45-53; oraz konkluzjom Pawła Paziaka przedstawionym w publikacji: Uwagi o semantyce nazw kolorów - ,bieli” i ,czerwieni” - w „Balladynie”, „Poradnik Językowy” 1997, z. 2, s. 18-24. Wszelkie zapożyczenia zostają jednak zreinterpretowane pod kątem problematyki tanatycznej.

29 M. Cieśla, op.cit., s. 53.

30 Zob. bidem. 
zagęszczenia tego słownictwa różni się we wszystkich trzech dramatach. Największą „krwawością”, rodem z powieści grozy, wyróżnia się Beatryks Cenci. Widać ją wyraźnie również w Balladynie. Natomiast w Kordianie-ze względu na motywację fabularną - jej intensywność jest dużo słabsza, chociaż i w tym dziele można dostrzec przejawy tego typu metody kreowania językowej przestrzeni Tanatosa. Po drugie, wspomniana leksyka dotyczy jedynie określonego rodzaju śmierci - śmierci nienaturalnej, zwłaszcza śmierci-zabójstwa ${ }^{31}$, mającej postać egzekucji, rzezi na polu walki, a przede wszystkim - umyślnego, dokonanego z premedytacją morderstwa. Ze względu na fakt, iż śmierć z ręki drugiego człowieka to na ogół śmierć gwałtowna i straszna, będąca całkowitym zaprzeczeniem tego, co zwyczajowo określa się mianem śmierci „,dobrej”, interesujące mnie słownictwo samoczynnie zyskuje negatywną wykładnię.

Ustalenie pejoratywnego nacechowania znaczeniowego jednostek leksykalnych wchodzących w skład omawianego zbioru bynajmniej nie wyczerpuje niesionych przez nie sensów. Ów zbiór odznacza się bowiem dużą funkcjonalnością semantyczną: te same wyrazy odnoszą się do różnych aspektów doświadczenia mortualnego i w zależności od kontekstu przyjmują inną wymowę. Wynika to m.in. z właściwości leksemów krew i czerwień, które są słowami treściowo złożonymi, mającymi rozbudowane znaczenia konotacyjne, promieniujące na wyrazy im pokrewne oraz pozostałe lingwistyczne wykładniki koloru czerwonego.

Zanim jednak złożona semantyka tanatyczna krwi i nazw barwy czerwonej zostanie szczegółowo scharakteryzowana, konieczne wydaje się zaprezentowanie zasobu leksyki, będącej przedmiotem niniejszej analizy ${ }^{32}$. Szereg „krwisty" tworzą słowo klucz krew i jego derywaty: przymiotnik krwawy, przysłówek krwawo, a także czasowniki krwawić, zakrwawić, skrwawić i okrwawić. Natomiast podstawę kanonu barwnego stanowią: przymiotnik czerwony, pochodny od niego rzeczownik czerwień oraz czasowniki poczerwienieć, czerwienić, zaczerwienić i sczerwienić. Jak zauważa Jan Grzenia, kolorystyczna „dziedzina słownictwa wyróżnia się niezwykłym bogactwem synonimiki”33, co potwierdza fakt występowania w opisywanym zbiorze przymiotników rdzawy, ognisty, rzeczowników szkarłat, purpura, a także rzeczowników i czasowników pośrednio przywołujących barwę czerwoną: malina, wino, zapalić.

Związek śmierci z krwią sprowadza się w omawianych utworach najczęściej do prostej zależności logicznej, w której krew stanowi fizyczną oznakę popełnio-

31 Por. ibidem, s. 49.

32 Jest to reprezentacja leksykalna wyekscerpowana z materiału ilustracyjnego. Omawiane wyrazy zostają przytoczone w formie słownikowej.

33 J. Grzenia, Założenia opisu pola semantycznego barw w języku polskim, „Poradnik Językowy" 1993, z. 4, s. 157. 
nego zabójstwa, dlatego leksyka z szeregu „krwistego” w większości przypadków wyraża treści realnoznaczeniowe. Także słownictwo „,barwne”, pojawiające się w tych kontekstach, odsyła do krwi jako dowodu śmiertelnej napaści.

Dowód ten w pierwszej kolejności znajduje się na osobie tragicznie zmarłej. Chcąc odsunąć od siebie podejrzenie o zamordowanie starego Cenciego, żona i dzieci nieboszczyka wynoszą zwłoki kazirodcy na ulicę, a następnie jego syn Fabrycy, udając wielkie zaskoczenie, krzyczy tak, by usłyszało całe miasto: „To Cenci leży skrwawiony - mój ojciec” (BC, 23). Podobnie Grzegorz, opowiadając Kordianowi o swoich wojennych przeżyciach, wspomina, jak Tatarzy zakatowali jednego z żołnierzy, ciagnąc go za koniem na powrozie: „Koń leciał jak strzała,/ Już trup zniknął - a jeszcze widać było konia/ I myśl przy koniu starca krwawego widziała" (Kor, 112).

Zbroczony krwią ofiary jest również jej oprawca. Fabrycy z Beatryks Cenci zwierza się matce, że spotkał trzy straszne Furie, gdy po zdobyciu Petreli „powracał [...] [do Rzymu - J.Ś.] krwawy” (BC, 12). Balladyna, która właśnie zamordowała Grabca, rozkazuje Fon Kostrynowi: „Przynieś mi światła; niech światło zobaczy,/ [...] Jak ja okropnie muszę być czerwona" (Bal, 464). Eumenidy, cieszące się ze zbrodni Beatryks, mówią, że widziały w gmachu leżącego trupa, a obok znajdowała się ,panna w krwi” (BC, 19).

Częściej jednak fakt wydarzenia się śmierci-zabójstwa ${ }^{34}$ zostaje w tekście zaakcentowany przez obdarzenie odpowiednim epitetem nazwy zakrwawionego narzędzia zbrodni lub jakiegoś innego przedmiotu czy szczegółu z miejsca rozegranej tragedii. W Balladynie Filon spostrzega, że obok martwej Aliny „rdzawel Leży żelazo” (Bal, 384). Kirkor, który podczas bitwy zabił srogiego Popiela, trzyma w ręku ,miecz zakrwawiony” (Bal, 448). Po ojcobójstwie dokonanym na Cencim w jego pokoju znaleziono „łóżko krwawe i sztylet pod łóżkiem” (BC, 49), a także odciśniętą na ścianie ,z prawej strony rękę krwawa [...] z pięcią palcami” (BC, 49). Prezes z Kordiana, wzbraniając się przed carobójstwem, zastanawia się, jakie będą konsekwencje tego czynu, jeśli ,jaki Antoniusz Europie pokaże/ Płaszcz skrwawiony Cezara” (Kor, 150), i podkreśla, że Polska nie będzie w stanie obronić się przed ewentualną zemstą ,sztyletu zakrwawiona stalą" (Kor, 150) ${ }^{35}$.

Odwołanie do krwi ludzkiej pojawiającej się w następstwie pozbawienia kogoś życia przynoszą też konstrukcje narzędnikowe z komponentem leksykalnym krew. Świadectwem śmierci dziecka stratowanego przez lud uciekający w Kordianie przed Wielkim Księciem są „krwiq polane bruki” (Kor, 141), a Aliny ginącej z ręki siostry - ,,splamione krwia [...] szaty” (Bal, 389) Balla-

\footnotetext{
34 Dotyczy to także zabójstwa rozpatrywanego w kategoriach potencjalnej możliwości.

35 W przykładzie tym konkrety w sposób metaforyczny oznaczają pojęcia abstrakcyjne.
} 
dyny oraz jej nóż „siny [, który - J.Ś.]/ Poczerwieniat krwiq” (Bal, 451). Natomiast bestialskie praktyki Popiela, żywiącego „karpie ciałem niewolników” (Bal, 338), demaskuja ,zaczerwienione krwiq [...] stawy” (Bal, 338). W dwóch ostatnich przykładach leksem krew zapewnia jednoznaczne odczytanie czasownikowi kolorystycznemu.

Znaczenie zbrukania, przekazywane przez słownictwo z grup „krwistej” i „barwnej”, nie daje się jednak zredukować tylko do rzeczywistego, fizycznego wymiaru. Wskazane wyrazy konotują również metaforyczny sens skalania. Objawia się ono w przyrodzie lub znamionuje psychikę bohatera-mordercy.

Tyrańskie rządy Popiela, obfitujące w nieprzypadkowe zgony jego poddanych, znaczą ziemie, którymi włada okrutnik, realną, ale i symboliczną krwią. Z tego powodu „sąsiad ziemię kata/ Na pośmiewisko zwie Rusią Czerwona" "36 (Bal, 338). Siostrobójstwo popełnione przez Balladynę skutkuje poszarganiem swoistego przymierza zawartego pomiędzy człowiekiem a Gają, dlatego czerwień przelanej krwi Aliny znajduje refleks w świecie natury. Odtąd bowiem „każda lilija, albo róża biała/ I na ślubie, i po ślubie/ [...] [jest - J.Ś.] plamami szkarłatu/ Na wszystkich liściach czerwona" (Bal, 389). Stąd też pytanie Pustelnika, wypowiedziane tuż po znalezieniu martwej dziewczyny: „Któż te pustynie krwiq czerwieni żywą?/ Czy tu król Popiel zawitał i plami/ Białe lilije naszych lasów" (Bal, 384).

Drugi kontekst, w którym leksyka krwi lub czerwieni implikuje cechę niefizycznego splamienia, dotyczy stanu psychicznego osoby uśmiercającej drugiego człowieka. Po zasztyletowaniu ojca Beatryks ma wrażenie, że jest jak „najbielsza z gołębic,/ Co się w kałuży krwawej chciała kapać/ I opryskała krwiq całą rodzinę" (BC, 88). Jej czystość i niewinność zostają skalane moralnym brudem popełnionego czynu, dlatego ,zgubiona, krwawa i przerażająca” (BC, 36) początkowo nie żywi nadziei na miłość Gianiego.

W wyekscerpowanym materiale językowym spotyka się również takie egzemplifikacje użycia leksemu krew, w których nie tyle wskazuje on na materialną substancję, ile - dzięki automatycznemu przeniesieniu skojarzeń bezpośrednio odsyła do negatywnie waloryzowanej ${ }^{37}$ śmierci-zabójstwa bądź śmierci-egzekucji. Wysuwając fałszywe oskarżenia, Fabrycy z Beatryks Cenci grozi Gianiemu i Cesariowi, że obaj zapłacą mu ,za krew ojca” (BC, 30). Podobnie Matka Cenci tuż przed egzekucją przeprasza swe dzieci za to, że się „oddała czarnym duchom - które/ Czyhały na [ich - J.Ś.] krew” (BC, 93). W tym samym utworze Giani, zgładziwszy księdza Negri, stwierdza, że „myśl

\footnotetext{
${ }^{36}$ Słowacki dokonuje reetymologizacji istniejącego toponimu.

${ }^{37} \mathrm{Z}$ wyjątkiem przykładu ostatniego, w którym negatywny wydźwięk zabójstwa zostaje złagodzony przez motywację patriotyczną.
} 
zaszczepiona przez [...] [Eumenidy - J.Ś.] stała się krwiq" (BC, 76). Aluzja do morderstwa, w tym przypadku śmiertelnego zamachu na cara, pojawia się także w śpiewie Nieznajomego z Kordiana: „A gdy przyszło zmartwychwstanie, Chrystus wino mienił w krew.../ [...] Trzeba wino w krew przemienić,/ Przemienione wino pić!..." (Kor, 142). Sens odebrania komuś życia, sugerowany przez krew, zostaje dodatkowo przypisany winu z powodu wspólnej cechy obu desygnatów, jaką jest czerwona barwa.

Oprócz tego słownictwo z ciąu „krwistego” służy określeniu właściwości przestępstw popełnianych przez postaci dramatyczne. Chodzi tu przede wszystkim o przymiotnik krwawy, stosowany przez Słowackiego w funkcji epitetu charakteryzującego, w dość tradycyjnym znaczeniu: 'odznaczający się okrucieństwem'. Przykładowo w Balladynie, w scenie sądu Kanclerz pyta Filona o to, kogo podejrzewa on o „zabójstwo krwawe” (Bal, 490) Aliny. Tak samo kardynał Orsini zapowiada, mając na myśli mord dokonany na ojcu Cencim, że „ta krwawa zbrodnia nie ujdzie [oprawcy - J.Ś.] bezkarnie” (BC, 58).

Kolejną pejoratywną wykładnię leksemu krew stanowi w analizowanych dramatach - zgodnie z tradycyjną symboliką ${ }^{38}$ - wina, wynikająca z faktu celowego uśmiercenia drugiego człowieka lub przyczynienia się do tego niegodziwego czynu. Starając się odsunąć od swojej rodziny podejrzenie o zabójstwo starego Cenciego, matka Beatryks nakazuje swym dzieciom: „Mieszajcie imię Orsinich - z przekleństwem/ Rzućcie krew jego na Orsinich głowy” (BC, 18). Pragnąc powstrzymać Fabrycego i Gianiego przed stanięciem do pojedynku, który niechybnie zakończyłby się śmiercią jednego z nich, Beatryks krzyczy: „Stojcie!... już dosyć krwi na mojej duszy!” (BC, 31). Podobnie Starzec z Kordiana, chcąc rozwiać obawy spiskowców co do wydania wyroku śmierci na carską rodzinę, ofiarowuje się: ,Zabijajcie!!!/ A krew niech na mnie spada [...]. Krew dziecka i kobiety sam wezmę - książęca/ Syny wezmą. - Dwóm córkom nieszczęsnym na głowy,/ Na dwie - bo słabe - rzucę lekką krew cesarza" (Kor, 152).

Szczególnie wyeksponowanym aspektem śmierci-zabójstwa, pozostającym w relacji ze wspomnianą wyżej winą, okazuje się naznaczenie zbrodniarza niezbywalnym piętnem. Ów symboliczny sens niesie nagromadzona leksyka „krwisto-barwna”, wykorzystana przez poetę do opisu dziwnej, nienaturalnej plamy, która po zabiciu siostry wykwita na czole Balladyny. Podstawą negatywnych skojarzeń związanych z tą plamą jest odniesienie do krwi ${ }^{39}$, przywodzącej na myśl akt morderstwa. Przerażona dopiero co popełnionym, okrutnym czynem Balladyna mówi, pokazując najpierw zapewne na ubranie, a następnie

\footnotetext{
${ }^{38}$ Zob. W. Kopaliński, op.cit., hasło Krew, s. 168.

39 Por. P. Paziak, op.cit., s. 20.
} 
na swoje czoło: „Krwi plama/ Tu - i tu - i tu -/ i tu” (Bal, 382). Później zaś, nie mogąc się jej pozbyć, woła: „Plamo krwawa, znikaj!” (Bal, 396).

Dalsza charakterystyka przebiega już na płaszczyźnie „,barwnej”, gdyż leksyka kolorystyczna zostaje umotywowana przez ,referencję krwi explicite zawartą w tekście”40: „Cóż to! jakaś plama,/ Jak krew czerwona?” (Bal, 394); „Niby miesiąc w mglistym kole/ Krwi... twoja rana... czerwona i sina./ Powiedz mi, jaka straszna wina [!]/ Przyczyną?” (Bal, 420). Dlatego Goplana podkreśla, że choć zabójczyni pozbędzie się zakrwawionych szat, „na czole plama zostanie czerwona" (Bal, 389), a zatroskana Wdowa, nie mogąc pomóc córce w usunięciu tego znamienia, mówi: „Jeszcze jest... by na osieci/ Listek czerwony..." (Bal, 395).

Drugi krag odniesień do „szatańskiej pieczątki” (Kor, 186) - że posłużę się tu wyrażeniem z Kordiana - trwale naznaczającej zbrodniarza tworzy się wokół leksemu malina ${ }^{41}$. Jego związki z krwiq zostają bezpośrednio uwypuklone w tekście. Kiedy Balladyna słyszy, że ma na czole czerwoną plamę, przestraszona pyta matkę: „Krew?” (Bal, 395). Ta jej natomiast odpowiada: „To od maliny/ Może... daj... zetrę..." (Bal, 395). Czynnikiem spajającym oba te leksemy jest asocjacja barwna, a dokładniej - wspólna dla krwi i maliny cecha ,czerwoności”, którą Słowacki zresztą wyraźnie podkreśla. Nadgoplańska władczyni tłumaczy Pustelnikowi, że to „czerwona malina/ Splamiła [jej - J.Ś.] czoło” (Bal, 420), a on, nie dowierzając tym wyjaśnieniom, pyta: „Czy ta malina była kiedyś białą?/ A tyś ją może sama sczerwieniła?” (Bal, 421). Dochodzi tu zatem, co stwierdza Paweł Paziak, do rozszerzenia znaczenia leksemu malina ${ }^{42}$ zostaje on bowiem wzbogacony o metaforyczny sens piętna, winy: „A malinal Na twoim czole?" (Bal, 412).

Należy podkreślić, że w Balladynie i Beatryks Cenci słownictwo z pola krwi oraz koloru czerwonego współtworzy lingwistyczną przestrzeń śmierci nie tylko za sprawą niesienia konkretnego sensu związanego z Tanatosem, ale także pełniąc funkcję specyficznego sygnału mortualnego ${ }^{43}$. Bardzo często zwłaszcza w Balladynie - pojawia się ono w opisach pejzażu jako znak projekcji duchowej niespokojności bohatera na sferę przyrody. Zgodnie z roman-

40 Ibidem.

41 Ibidem.

42 Ibidem.

43 Omawiając znaczenie nazw barwy czarnej (ciemnej) w Beatryks Cenci, Maria Cieśla zauważa, że w niektórych miejscach fabularnych wykracza ono poza funkcję ,konkretnie umotywowaną", tak iż barwa ta zaczyna odgrywać rolę ,plamy czy sygnału kolorystycznego”, odnoszącego się do ,pewnego zespołu emocji”. Podobną, również „niekonkretnie umotywowaną”, funkcję zauważam w przypadku leksemu krew i nazw barwy czerwonej w kontekście ich związku z tematyką śmierci, dlatego też nazywając ową funkcję, nawiązuję do określenia wprowadzonego przez badaczkę. Zob. M. Cieśla, op.cit., s. 48. 
tyczną koncepcją jedności człowieka i natury przyroda stanowi bowiem jak gdyby lustro, w którym znajdują swe odbicie różne zdarzenia ze świata ludzkiego ${ }^{44}$. Ze względu na fakt, że owa niespokojność skutkuje nierzadko zadaniem komuś śmierci, leksyka krwi i czerwieni staje się - w planie fabularnym dramatu - złowrogim zwiastunem wątków tanatycznych. Podczas „wyścigu” o koronę, a więc tuż przed zabiciem Aliny, Balladyna mówi: „Jak mało malin! a jakie czerwonel By krew [...] A niebo jakie zapalone / Jak krew... Czemu ty, słońce, wschodzisz krwawo?” (Bal, 377-378). Natomiast w drodze na wieżę, gdzie nastąpi rzeź dokonana na Grabcu, morderczyni zwraca się do błyskawic: „O! błyskawice,/ Stwórzcie czerwony dzień na łonie nocy,/ Bądźcie mojego czynu słońcem” (Bal, 463) i faktycznie drogę tę oświetla jej ,błyskawica czerwona" (Bal, 463).

Krwistoczerwony pejzaż - jako omen śmierci - nie musi jednak wskazywać na akt zabójstwa. Może po prostu zapowiadać niebezpieczeństwo, jakim jest śmierć czekająca któregoś z bohaterów. Tak się właśnie dzieje przed tragicznym zgonem Balladyny od uderzenia pioruna, kiedy to niebo ma „łono [...] z purpury/ Ognistej...” (Bal, 483). Podobnie Beatryks, oczekując w więzieniu na wyrok za ojcobójstwo, obserwuje, jak ,słońca smutny snop - jako czerwony/ Piorun bez huku - ze sklepień upada/ I trwa w powietrzu ciemnym nieruchomy/ Krwawiac ciemności środek" (BC, 66). Warto zauważyć, że w przytoczonych przykładach pojawiają się dwa prototypowe odniesienia czerwieni - zarówno do krwi, jak i do ognia ${ }^{45}$.

W Beatryks Cenci wyrazy z pola semantycznego barwy czerwonej oraz szeregu „krwistego” w roli znaku wyprzedzającego tragiczne wydarzenia nie są przypisane jedynie do obrazów natury. Występują one w różnych partiach fabularnych i opcjonalnie pozostają w pewnej zależności ze stanem psychicznym bohaterów.

Jeszcze przed zamordowaniem Cenciego przez Beatryks Trzecia Furia mówi, iż mężczyzna poszedł spać „do krwawego łoża” (BC, 9) i określa dom Cencich jako ,puteń krwi” (BC, 9). Fabrycy opowiada matce, że kiedy, wracając z bitwy, spotkał Eumenidy, ,krew [...] walką rozdąsana w żyłach,/ Zalała [...] [jego - J.Ś.] oczy - i te mary/ Ubrała w czerwień straszną" (BC, 12), jeszcze zanim zdradziły mu jego straszne przeznaczenie. Potem zaś tchórzy

${ }^{44}$ Alina Kowalczykowa twierdzi natomiast, że w Balladynie korelacja pomiędzy człowiekiem a naturą ma jeszcze głębszy charakter - nie ogranicza się bowiem do ,paralelizmu zachowań”. Na obraz przyrody nakładają się stany duchowe postaci dramatycznych, ale pejzaż nie stanowi jedynie ,ekranu” dla ludzkich projekcji, jest on także swego rodzaju bodźcem do zbrodniczych działań bohaterów. Zob. A. Kowalczykowa, Słowacki, Warszawa 1999, s. 211-212.

${ }_{45}$ Zob. M. Białoskórska, Dzieje poetyzmów ,, koral” i ,,rubin” w języku polskim, „Poznańskie Spotkania Językoznawcze” 2001, t. 7, s. 33. 
przed popełnieniem zbrodniczego czynu, ponieważ widzi „,w korytarzu [...] trzy mary/ [, które - J.Ś.] [...] w rękach mają krwawe chusty” (BC, 16). Z kolei mały Azo tuż przed utratą ojca wyznaje matce: „Ciagle przed oczyma/ Jakieś czerwone latają mi plamy/ Jakby czerwone gołąbki...” (BC, 15).

Inna funkcja słownictwa aktualizującego motyw krwi lub będącego wykładnikiem czerwonej barwy, zastosowanego przez poetę w Beatryks Cen$c i$ - również nie stricte znaczeniowa - polega na wprowadzaniu do tekstu nieprzyjemnej (mówiąc eufemistycznie) jakości emocjonalnej, charakteryzującej przeżycia wewnętrzne bohaterów. Leksyka ta umożliwia Słowackiemu zobrazowanie „niezwykłego napięcia psychicznego"46, stającego się udziałem postaci dramatycznych z powodu opanowującej ich umysł myśli o śmierci własnej bądź cudzej, mającej już miejsce lub dopiero przewidywanej.

Prześladowana świadomością popełnionej zbrodni Beatryks czuje przed wpadnięciem w dziwny letarg, że oczy się jej „kleją,/ Jakby na rzęsach krew zgęstniała lipka" (BC, 51). Kiedy zasypia, pojawia się cień ojca Cenci, który mówi: „Owinąć ją krwi chmura/ Ciężką - ciemną - ponurą.../ Spij, czerwona, spij, czerwona!/ Jeśli się zbudzi, to wrzaśnie i skona./ Bies! bies! bies!/ Trup się [z] trumny wyrywa/ I chce kąsać jak wściekły pies.../ We mgle okrwawionej pływa" (BC, 51). Potem w kościelnych katakumbach, gdzie znajduje się trumna zamordowanego ojca, dziewczyna ścieli „skrwawionq pościel trupa” (BC, 54), a jej oczy z trumny tej ,przez szczeliny/ Krew wysysaja” (BC, 54). Mało tego, czerwień i krew udzielają się samej naturze śmierci, która w odczuciu bohaterów jest ,przepaścią czerwona” $(\mathrm{BC}, 42)$ i jawi się im jako ,morze ze krwi promienistej” (BC, 66) czy też „morze krwi” (BC, 105).

W świetle przeprowadzonej analizy można stwierdzić, że w Kordianie, Balladynie i Beatryks Cenci szczególną unikatowością wyróżniają się te wyobrażenia mors, które ukazuja jej negatywne oblicze. Akcent pada w nich na drapieżność, zachłanność oraz okropieństwo śmierci, jej okrutny i mroczny charakter, a także na czynione przez nią spustoszenia w sferze cielesnej człowieka. Taki - ujemnie waloryzowany - obraz przynoszą przede wszystkim poetyckie metafory i personifikacje, budowane nierzadko na bazie utartych połączeń wyrazowych, oraz niektóre zastępniki nazewnicze, zwłaszcza z kręgu semantycznego 'odebranie komuś życia'. Pejoratywną wykładnią zostają również obciążone z upodobaniem stosowane przez Słowackiego - zwłaszcza

${ }^{46}$ M. Cieśla, op.cit., s. 52. 
w Balladynie i Beatryks Cenci - słowo klucz krew (wraz z derywatami) oraz nazwy barwy czerwonej, konotujące rozmaite sensy tanatyczne i uwydatniające frenetyczne skłonności poety. Całość posępnej wizji śmierci dopełniają smutne jakości emocjonalne wyrażane przez określenia zastępcze i figury stylistyczne odnoszące się do różnych elementów kultury funeralnej.

\section{Joanna Ścibek}

\section{Juliusz Słowacki's theatrum mortis - a negative projection (on the basis of Kordian, Balladyna and Beatryks Cenci)}

The author's intention is to present the most important techniques applied by Słowacki intended to evoke a negative projection of death in three dramas written in the pre-mystic period: Kordian, Balladyna and Beatryks Cenci. The excerpted material is analysed semantically and lexically in view of its semantic contexts concerning human death. The basis of the reconstruction of the negative creation of mors, featured in these works, is provided by a description and discussion of the figures of speech and rhetorical devices with a lexical component that belongs to the semantic field 'death' (metaphors and personifications in particular), as well as substitute designations for designates that are related to the phenomenon of the passing of time where one's life is slowly coming to an end. In addition, the author provides a characteristics of the Thanatic semantics of the lexeme blood and derivatives thereof, as well as names for the colour red. Verbal realizations of such conceptual constructions highlight such features of deaths as: mysteriousness, ghastliness, rapaciousness, perversity, brutality and cruelty that imply the feeling of sadness, fear and repulsion. It should be noted, however, that the "theater of death", presented by Słowacki in the dramas, is of ambivalent nature because the negative manifestations of Thanatos are at the same time supplemented with euphemistic approaches aimed at easing the tension, softening the horror of death and camouflaging its terrifying dimension. These approaches are discussed in the following article: Juliusza Stowackiego "theatrum mortis" na przykładzie "Kordiana", "Balladyny" $i$ "Beatryks Cenci" - wizja ułagodzona.

KEY wORDs: Słowacki, dramas, death, negative projection.

mgr Joanna Ścibek, słuchaczka II roku filologicznych studiów doktoranckich na Wydziale Filologicznym Uniwersytetu w Białymstoku; zainteresowania badawcze: język artystyczny, semantyka lingwistyczna oraz kognitywizm. 